\title{
Spontaneous regression of a biopsy confirmed hepatocellular carcinoma
}

\author{
Neil Bhardwaj, ${ }^{1}$ Mo Li, ${ }^{2}$ Timothy Price, ${ }^{2}$ Guy J Maddern ${ }^{2}$
}

${ }^{1}$ Leicester General Hospital,

Leicester, UK

${ }^{2}$ The Queen Elizabeth Hospital,

Adelaide, Australia

\section{Correspondence to}

Neil Bhardwaj,

neilbhardwaj@yahoo.co.uk

Accepted 7 July 2014
CrossMark

To cite: Bhardwaj N, Li M, Price T, et al. BMJ Case Rep Published online: [please include Day Month Year] doi:10.1136/bcr-2014204897

\section{SUMMARY}

A 74-year-old woman was diagnosed with histologically proven multiple bilobar hepatocellular carcinomas (HCC) in 2012. The lesions were inoperable and a repeat CT scan prior to starting chemotherapy revealed spontaneous regression of these lesions. Subsequent repeat scans have revealed continued regression of these lesions despite no active treatment. The case is presented with a literature review and discussion summarising the possible aetiologies of this phenomenon.

\section{BACKGROUND}

Spontaneously regressing hepatocellular carcinomas (HCC) are extremely rare and this case was the first we have seen in a professorial liver unit where approximately 200 patients with liver lesions are discussed in multidisciplinary meetings every year. There are several important messages to be learnt from this case.

\section{CASE PRESENTATION}

A 74-year-old woman presented to her general practitioner in June 2012 with a vague back pain and was found to have microscopic haematuria. A renal ultrasound scan and subsequent abdominal CT scan in July 2012 demonstrated at least 20 hypervascular lesions in her liver with the largest measuring $7 \mathrm{~cm} \times 9 \mathrm{~cm}$, located in the inferior left lobe. There was no extended history of alcohol misuse and she had history of hypertension, cholecystectomy and tubal ligation. Blood test showed deranged liver enzymes with normal alkaline phosphatase and bilirubin. Her tumour markers $(\alpha$-fetoprotein (AFP), CA 19.9 and CA 125) were negative as were viral hepatitis serologies. The lesions were deemed inoperable and after discussion in our hepatobiliary multidisciplinary meeting, biopsy of one of these liver lesions was organised and it confirmed the diagnosis of a welldifferentiated hepatocellular carcinoma.

She was reviewed by the oncologist in September 2012, who arranged a restaging CT as her liver function tests had returned to normal and her past CT was over 2 months old. This scan, in September 2012, showed a dramatic reduction in the number and size of the lesions. An independent pathologist, who was blinded to the initial result, reviewed the biopsy results and the diagnosis of welldifferentiated HCC was reconfirmed. She continues to remain asymptomatic and serial CT scans (April and December 2013) have continued to show either regression or resolution of all lesions (figure 1-arterial phase, figure 2-venous phase).

\section{INVESTIGATIONS}

Tumour markers, liver function tests and CT scans as above.

\section{DIFFERENTIAL DIAGNOSIS}

Benign adenoma and focal nodular hyperplasia can have similar histological appearances to welldifferentiated HCC. However immunostains help distinguish benign from malignant lesions.

\section{TREATMENT}

Watch and wait with serial CT scans.

\section{OUTCOME AND FOLLOW-UP}

Latest scans show continued regression of lesions.

\section{DISCUSSION}

Globally, liver cancer is the second leading cause of cancer-related death in men and sixth in women with poor 5 year survival if inoperable and $50 \%$ if operable. Over 1300 new cases per year are diagnosed in Australia, which account for $1.1 \%$ of all new cancers. ${ }^{1-3}$ Partial or spontaneous regression of HCC has been described before; however the majority of cases are described in the East and on the background of liver disease and/or raised $\mathrm{AFP}^{4-13}$ Although rare, this phenomenon draws attention and provides hope to clinicians to find cure of HCC by understanding the underlying mechanism of spontaneous regression. Although no definitive mechanism has been elucidated, the two most popular theories are related to induction of ischaemia and the body's immunological response. ${ }^{14}$

A systemic review estimated the rate of partial objective regression to be around $0.5 \%{ }^{4}$ and a literature review conducted by Huz et al ${ }^{15}$ in 2012 suggested that at least one-third of the cases with spontaneously regressing HCC were related to the systemic immune response. T-cell activation by antigenpresenting dendritic cells allows the body to mount a specific and long-lasting antitumour response as demonstrated in animal models of HCC that received vaccination of AFP as an antigen. ${ }^{16}$ Other potential antigens in HCC include the melanoma antigen gene family and glypican-3. ${ }^{16}$ The same theory is used to explain regressions after rupture of the tumour or seeding of malignant cells via biopsy or surgery. ${ }^{17}$ Elevation of cytokines IL- $18^{18}$ and TNF $\alpha^{19}{ }^{20}$ in cases of spontaneously regressing HCC suggest that a systemic immune response may be responsible for this rare phenomenon. 
Figure 1 Serial arterial scans.

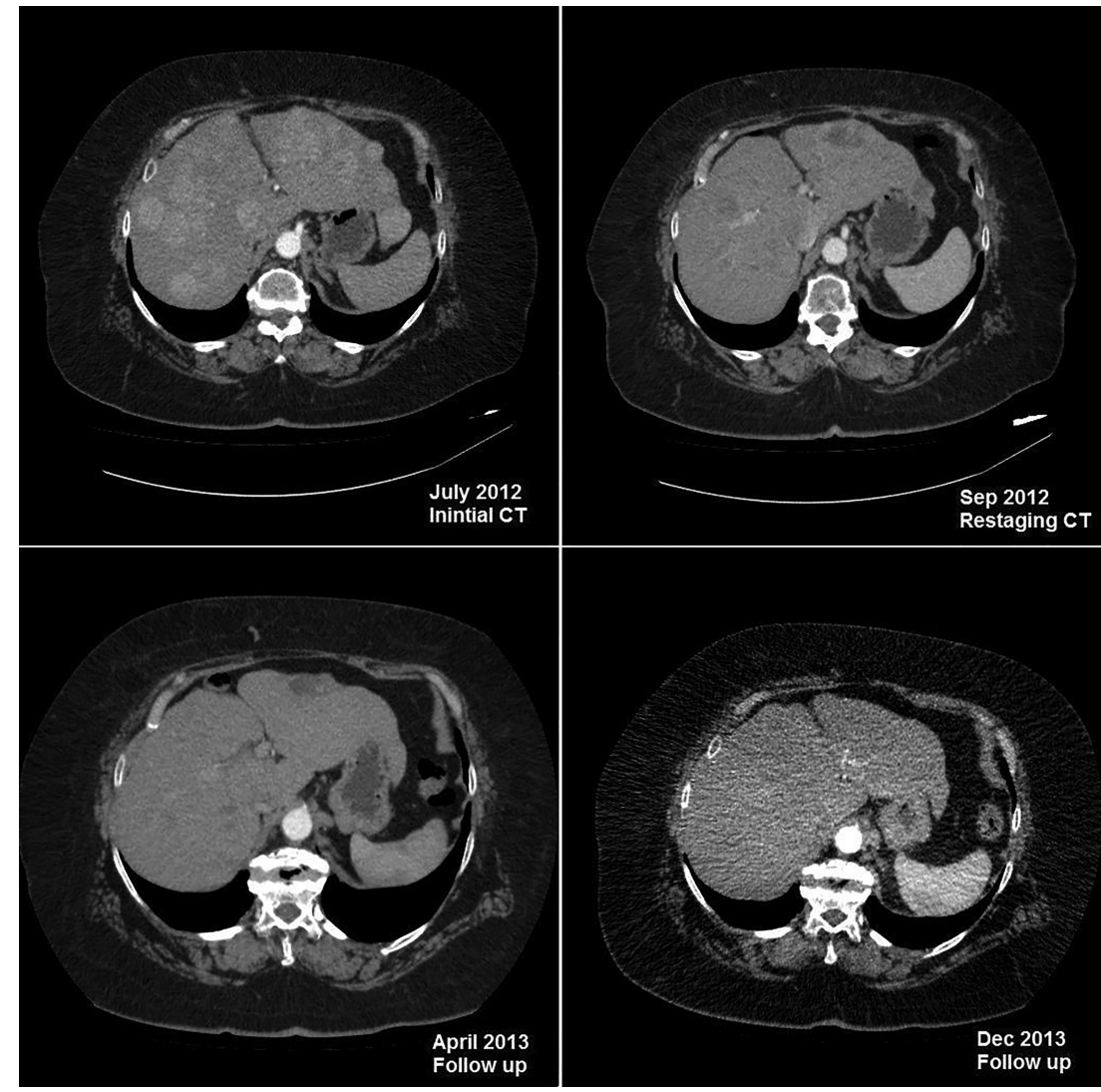

Necrosis resulting from ischaemia or tumour hypoxia via variable mechanisms is a potential cause for regression of HCCs. In Huz's report, $28 \%$ of spontaneous regressions of HCC were as a result of tumour ischaemia. ${ }^{15}$ Disruption of blood supply, either due to the local effect of vascular injury, ${ }^{21}$ aterioportal shunt $^{22}$ or portal vein thrombosis ${ }^{23}$ or due to the systemic

Figure 2 Serial venous scans.

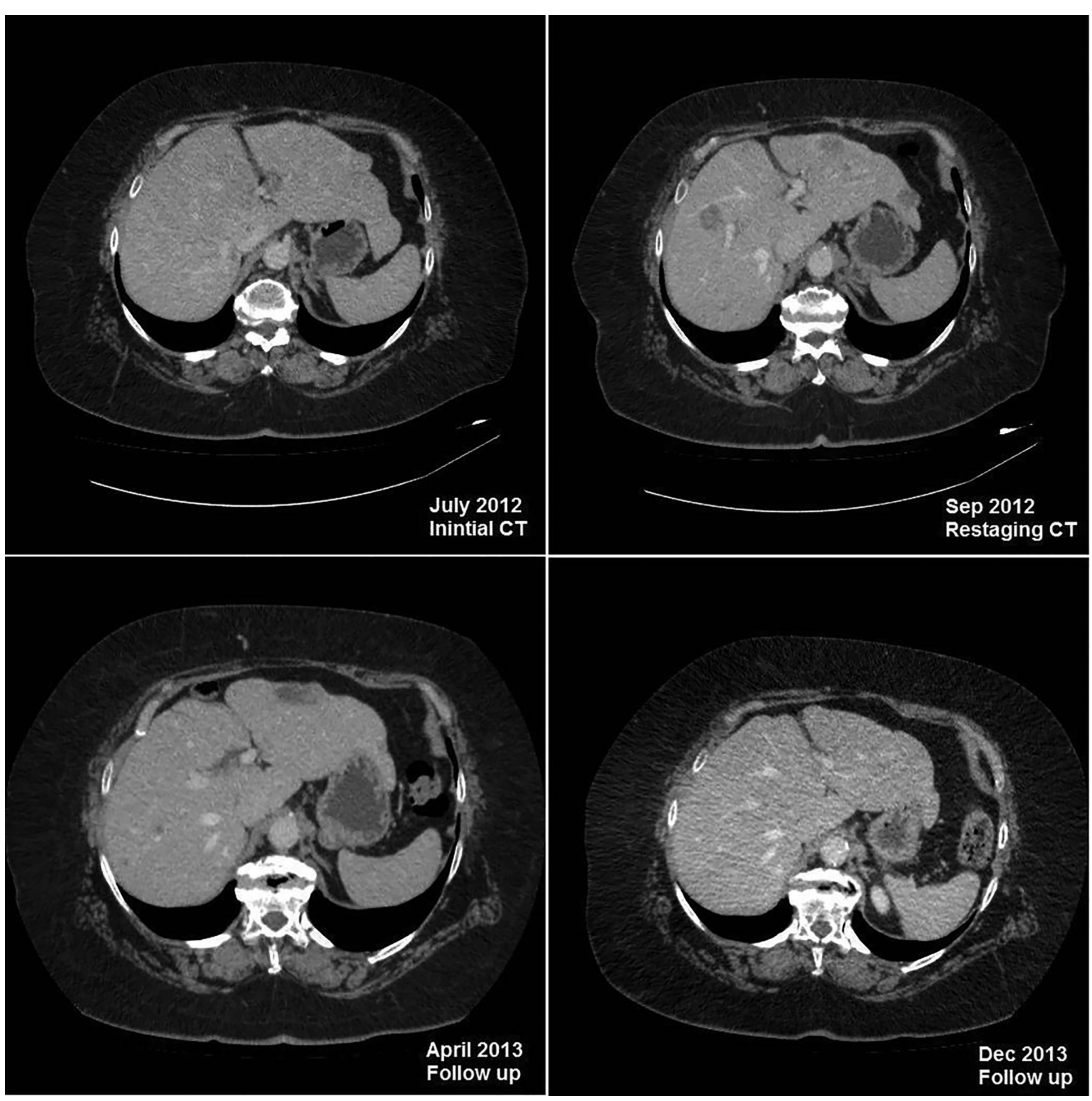


hypoperfusion from bleeding, ${ }^{24}$ can lead to necrosis and regression of hepatocellular carcinoma. This mechanism is exploited artificially by hepatic artery embolisation and antiangiogenic agents such as sorafenib, which are well-known therapeutic manoeuvres that induce tumour hypoxia and subsequent regression. $^{15}$

\section{Learning points}

- This case adds to the world literature on spontaneously regressing hepatocellular carcinomas (HCC).

- Unlike the vast majority of cases, this HCC developed on a background of a normal liver and $\alpha$-fetoprotein.

- It is imperative to restage the patient if the presenting symptoms subsides or the patient's blood tests improve (as it was the case here).

- A rebiopsy is not necessary, however the original pathology should always be reviewed if there is any doubt regarding the diagnosis.

Contributors NB and ML wrote the manuscript and all authors contributed equally to the manuscript design, literature search and editing of the final manuscript.

\section{Competing interests None.}

Patient consent Obtained.

Provenance and peer review Not commissioned; externally peer reviewed.

\section{REFERENCES}

1 Jemal A, Bray F, Center MM, et al. Global cancer statistics. CA Cancer J Clin 2011;61:69-90.

2 AlHW. Cancer in Australia: an overview, 2012. Australian Institute of Health and Welfare \& Australasian Association of Cancer Registries 2012 Cancer series. vol 74. 2012.

3 AlHW C. Cancer survival and prevalence in Australia: period estimates from 1982 to 2010. Australian Institute of Health and Welfare 2012 Cancer Series. vol 69. 2012.

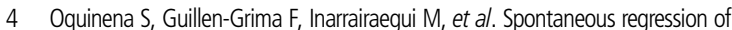
hepatocellular carcinoma: a systematic review. Eur J Gastroenterol Hepatol 2009;21:254-7.
5 Hsu CY, Sun PL, Chang HC, et al. Spontaneous regression of advanced hepatocellular carcinoma: a case report. Cases J 2009;2:6251.

6 Ohtani $\mathrm{H}$, Yamazaki O, Matsuyama M, et al. Spontaneous regression of hepatocellular carcinoma: report of a case. Surg Today 2005;35:1081-6.

7 Feo CF, Marrosu A, Scanu AM, et al. Spontaneous regression of hepatocellular carcinoma: report of a case. Eur J Gastroenterol Hepatol 2004; 16:933-6.

8 Lin TJ, Liao LY, Lin CL, et al. Spontaneous regression of hepatocellular carcinoma: a case report and literature review. Hepatogastroenterology 2004;51:579-82.

9 Matsuo $\mathrm{R}$, Ogata $\mathrm{H}$, Tsuji $\mathrm{H}$, et al. Spontaneous regression of hepatocellular carcinoma-a case report. Hepatogastroenterology 2001;48:1740-2.

10 Barreca G, Lucisano A, Lauria A, et al. [Spontaneous regression of hepatocellular carcinoma. Report of a case]. Radiol Med 2000;99:482-4.

11 Jang TJ, Lee Jl, Kim DH, et al. Spontaneous regression of hepatocellular carcinoma - a case report. Korean J Intern Med 2000;15:147-50.

12 Iwasaki M, Furuse J, Yoshino $\mathrm{M}$, et al. Spontaneous regression of hepatocellular carcinoma: a case report. Jpn J Clin Oncol 1997;27:278-81.

13 Suzuki M, Okazaki N, Yoshino $M$, et al. Spontaneous regression of a hepatocellular carcinoma-a case report. Hepatogastroenterology 1989;36:160-3.

14 Arora N, Madhusudhana S. Spontaneous regression of hepatocellular cancer: case report and review of literature. Gastrointest Cancer Res 2011:4:141-3.

15 Huz JI, Melis M, Sarpel U. Spontaneous regression of hepatocellular carcinoma is most often associated with tumour hypoxia or a systemic inflammatory response. HPB (Oxford) 2012;14:500-5

16 O'Beirne JP, Harrison PM. The role of the immune system in the control of hepatocellular carcinoma. Eur J Gastroenterol Hepatol 2004;16:1257-60.

17 Blondon $\mathrm{H}$, Fritsch L, Cherqui D. Two cases of spontaneous regression of multicentric hepatocellular carcinoma after intraperitoneal rupture: possible role of immune mechanisms. Eur J Gastroenterol Hepatol 2004;16:1355-9.

18 Abiru S, Kato Y, Hamasaki K, et al. Spontaneous regression of hepatocellular carcinoma associated with elevated levels of interleukin 18. Am J Gastroenterol 2002;97:774-5.

19 Mochizuki T, Takehara Y, Nishimura T, et al. Regression of hepatocellular carcinoma. AJR Am J Roentgenol 1991;156:868-9.

20 Ohba K, Omagari K, Nakamura T, et al. Abscopal regression of hepatocellular carcinoma after radiotherapy for bone metastasis. Gut 1998;43:575-7.

21 Takayasu K, Muramatsu Y, Shima Y, et al. Necrosis of hepatocellular carcinoma as a result of subintimal injury incurred by hepatic angiography: report of two cases. Am J Gastroentero/ 1986;81:979-83.

22 Misawa K, Hata Y, Manabe K, et al. Spontaneous regression of hepatocellular carcinoma. J Gastroenterol 1999:34:410-14.

23 Uenishi $\mathrm{T}$, Hirohashi $\mathrm{K}$, Tanaka $\mathrm{H}$, et al. Spontaneous regression of a large hepatocellular carcinoma with portal vein tumor thrombi: report of a case. Surg Today 2000;30:82-5.

24 McDermott WV, Khettry U. Clear cell carcinoma of the liver with spontaneous regression of metastases. J Surg Oncol 1994;57:206-9.

Copyright 2014 BMJ Publishing Group. All rights reserved. For permission to reuse any of this content visit

http://group.bmj.com/group/rights-licensing/permissions.

BMJ Case Report Fellows may re-use this article for personal use and teaching without any further permission.

Become a Fellow of BMJ Case Reports today and you can:

- Submit as many cases as you like

- Enjoy fast sympathetic peer review and rapid publication of accepted articles

- Access all the published articles

- Re-use any of the published material for personal use and teaching without further permission

For information on Institutional Fellowships contact consortiasales@bmjgroup.com

Visit casereports.bmj.com for more articles like this and to become a Fellow 